\title{
Hakham Yaakov Athias-A Portuguese Rabbi Facing the Winds of Enlightenment and Secularization
}

\author{
Yocheved Beeri
}

The Jewish community of Bordeaux, like the other Sephardic communities in the southwest of France, emerged from groups of New Christians, decedents of Jewish converts who left Spain and Portugal from the sixteenth century onward and settled in France as Portuguese merchants. ${ }^{1}$ As such, they received certain legal rights in various royal Lettres Patentes along the centuries and were recognized as a "Nation" of merchants. ${ }^{2}$ In the Lettres Patentes of 1722 they were recognized as Jews for the first time. This gradual transition from a kind of clandestine Judaism to established communities acknowledged by the Jewish world reached its completion by the last quarter of the seventeenth century. ${ }^{3}$

In the beginning of the eighteenth century Bordeaux boasted an organized and vibrant Jewish community. It was led by a council of elders, or Assembly of the Nation, which represented the richest and most influential families.

1 On the Bordeaux community, see Louis Francia-Beaufleury, Histoire de l'établissement des Juifs à Bordeaux et à Bayonne depuis 1550 (Paris, an 8 [180o]); Arnaud Detcheverry, Histoire des Israélites de Bordeaux (Bordeaux: Balarac jeune, 1850); Théophile Malvezin, Histoire des Juifs à Bordeaux (Bordeaux: Charles Lefebvre, Libraire, 1875); Georges Cirot, Recherches sur les Juifs espagnols et portugais à Bordeaux (Bordeaux: Feret \& Fils, Éditeurs, 1908); Cirot, Les Juifs de Bordeaux. Leur situation morale et sociale de 1550 à la Révolution (Bordeaux: Feret, 1920); Gérard Nahon, Juifs et judaïsme à Bordeaux (Bordeaux: Mollat, 2003).

2 On the legal status of the New Christians in France, see Peter Sahlins, Unnaturally French: Foreign Citizens in the Old Regime and After (Ithaca: Cornell University Press, 2004), 51-52, $163^{-64 .}$

3 Gérard Nahon, "From New Christians to the Portuguese Jewish Nation in France," in Moreshet Sepharad, ed. Haim Beinart (Jerusalem: Magnes Press, 1992), 2: 336-43; Nahon, Métropoles et périphéries Séfarades d'occident (Paris: Cerf, 1993), 235-38; Frances Malino, The Sephardic Jews of Bordeaux (Tuscaloosa: University of Alabama Press, 1978), 3. On the religious identity of the conversos and how it changed with the migration from the Iberian Peninsula see David L. Graizbord, Souls in Dispute: Converso Identities in Iberia and the Jewish Diaspora, 1580-170o (Philadelphia: University of Pennsylvania Press, 2004).

(C) YOCHEVED BEERI, 2019 | DOI:10.1163/9789004392489_017

This is an open access chapter distributed under the terms of the prevailing CC-BY-NC License at the time of publication. 
The council met a few times a year and decided on the long-term matters of the community such as securing the renewed approval of the royal privileges, helping the poor, managing the cemetery, and collecting the communal taxes. Once a year it appointed a syndic and two assistants-a gabbay and parnassim — who dealt with the daily affairs. ${ }^{4}$

The community possessed a Jewish cemetery and a ritual bath (mikveh) with a paid attendant. There was a butcher shop that supplied the kosher meat, and several ritual slaughterers, approved or nominated by the community, performed the ritual slaughter of the animals. The community also managed the baking of the matsa, the unleavened bread eaten during Passover, and supplied and subsidized a mostly religious education to its children by an appointed teacher, or later, in a Talmud Torah, a religious school. ${ }^{5}$

The religious life in Bordeaux, apart from the services provided by the leadership and the above-mentioned institutions, emanated as well, or even more, from the public itself. According to an official report by Monsieur Pudeffer from 1733, there were six Portuguese synagogues located in private residences in Bordeaux, each one with its own leadership. Monsieur Pudeffer also related some religious practices of the Jews in Bordeaux:

[On Saturday, the Jews], their leaders, wives, children and servants go regularly to pray in their synagogues. [...] On these days their shops are closed as on Sundays and they refrain from any commerce. All their leaders, their wives, children etc. carry publicly in their hands when they go to the synagogue their prayer books, their white mantles and other adornments required by their religion. Sometimes they go barefoot, with the back of their shoes folded like slippers and knock-kneed, or with their hat-sides dropped down upon their eyes. [...] Their principal Holidays take place in September for the cabins, in March for their Easter, and during forty days they pray from midnight till daybreak. ${ }^{6}$

This last item refers evidently to the Selihot (penitential prayers recited in the period before the High Holidays) according to the Sephardic custom.

Various voluntary societies, or fraternities, were established in the community of Bordeaux. These fraternities, also called "yeshivot," played a central role

4 Simon Schwarzfuchs, Introduction to Registre des deliberations de la Nation juive Portugaise de Bordeaux 1710-1787 (Paris: Fundação Calouste Gulbenkian, Centro Cultural Português, 1981), 9-24; Nahon, "From New Christians to the Portuguese Jewish Nation in France," $348-52$.

5 Schwarzfuchs, Registre, 30.

6 Archives Départementales de la Gironde, C 1090, and Schwarzfuchs, Registre, 600-1. 
in the religious life of the Nation. They served as social associations that took care of the daily religious needs of their members, attended to the poor, or provided for burials and the mourners' necessities. Some researchers suggest that the community's establishment evolved from a society for the support of the poor, the Sedaka. Several fraternities maintained their own synagogues, and probably formed groups to study Torah as well, hence the name "yeshiva." The most important society was the Hevra, an abbreviation for Hevra Kadisha, the burial society. Other societies were the Yeshiva Le-Gmilut Hasadim, Yeshiva Le-Bikur Holim, Tiferet Bahurim, Yeshivat Mishenet Holim, and Tiferet Shalom. ${ }^{7}$

\section{$2 \quad$ Transgressions}

In spite of this lively Jewish religious life, the community of Bordeaux was criticized internally and externally for its religious laxity and frequent transgression of the commandments by some of its members. The community register, which is a collection of the resolutions of the assembly of elders, mentions from 1733 to $175^{1}$ a few members who were punished by the community for leading a disreputable life, for speaking against the Jewish religion and its commandments, and for breaking the Sabbath and holidays. ${ }^{8}$ Hertzberg suggested that the absence of further decisions of punishments for these offences demonstrates the diminishing interest of the community in punishing the offenders rather than their diminishing numbers. ${ }^{9}$

Doubts about the integrity of the Bordeaux community and its full commitment to the Jewish religious laws emerge over the course of the eighteenth century. Recurring conflicts arose between the Jewish communities of Hamburg and Altona and the community of Bordeaux over the supervision and certification of the latter's wine production in 1719, 1737, and again in the early fifties. Bordeaux was understandably an important producer and supplier of kosher wine for a range of Jewish communities throughout Europe. The wine importers of Hamburg placed a supervisor on their behalf in Bordeaux whose mission was to oversee the kosher wine production. Accordingly, they refused to pay

7 Schwarzfuchs, Registre, 29, 113-18, 197-98, 243-46; Nahon, Métropoles et périphéries Séfarades d'occident, 315 .

8 Schwarzfuchs, Registre, 133, 137, 188-90, 213-14, 225.

9 Arthur Hertzberg, The French Enlightenment and the Jews: The Origins of Modern AntiSemitism (New York: Schocken Books, 1968), 160-61. 
the tax to the Bordeaux community for the kosher certification of the wine. ${ }^{10}$ In spite of the obvious economic interests involved in this conflict, it attests also to the suspicions of the Hamburg community regarding the Bordeaux community's strict adherence to halakha.

Another subject of reproach was the women's observance of ritual immersion, an essential part of the family purity laws. In 1728, probably following the visit to Bordeaux of an emissary from the Holy Land, the hakhamim of Safed sent a letter to the gabbay and parnassim of Bordeaux accusing the community's women of neglecting their observance and demanding from the leadership to inquire after those who do not bathe in a mikve according to the rules of purity. This letter initiated an interesting exchange between the hakhamim of Safed, the Mahamad of the Amsterdam community, and the leadership of the community of Bordeaux regarding the ritual bathing of women in Bordeaux. This correspondence has been extensively analyzed by Evelyne Oliel-Grausz. ${ }^{11}$

An allegation about the negligence of ritual bathing appears also in the personal account of Rabbi Haim Yosef Azulay, also known as Hida, regarding his visit to Bordeaux in 1777. Hida, an emissary of Hebron to Europe who visited Bordeaux twice on his journeys, didn't rely on the Bordeaux community's ritual slaughter and didn't eat their meat, despite his examination of the slaughterers on his 1755 visit and his disqualifying of some and approving of others. He didn't even eat dairy or fish at the Portuguese community's communal table. ${ }^{12}$ In 1777 , Hida also accused some members of the community of breaking the Sabbath and of eating forbidden foods in public. ${ }^{13}$

10 On the production of kosher wine and its distribution to the communities of the Sephardic diaspora, see Nahon, "From New Christians to the Portuguese Jewish Nation in France," 344; Nahon, Métropoles et périphéries Séfarades d'occident, 141-42; Evelyne Oliel-Grausz, "Relations et réseaux intercommunautaires dans la diaspora séfarade d'occident au XVIII ${ }^{\mathrm{e}}$ siècle," PhD diss., University of Paris, 1999, 384-90; Malvezin, Histoire des juifs a Bordeaux, 201-6. On the conflicts regarding Kosher wine certification, see Schwarzfuchs, Registre, 96-99, 144-46; Stadsarchief Amsterdam [hereafter SAA] 334/5.1.1.90, Copiador de cartas 1702-1719, 158; Archives Départementales de la Gironde, C 1089, nn. 44, 45, 46, $57,58,59,62,64,65,67,72,74,75$.

11 Schwarzfuchs, Registre, 113-14; SAA 334/5.1.1.107, Borador de cartas 1719-1728, fols. 87-90; Oliel-Grausz, "Relations et reseaux," 507-12; idem, "La diaspora séfarade au XVIII" siècle: communication, espaces, réseaux," Arquivos do Centro Cultural Calouste Gulbenkian 48 (2004): $57-58$.

12 Schwarzfuchs, Registre, 270-71; Haim Yosef David Azulai, Ma'agal Tov ha-Shalem, ed. Aharon Freiman (Jerusalem: Merkaz ha-Sefer, 1983), 35-36. On Hida's visits to Bordeaux, see Nahon, Métropoles et périphéries Séfarades d'occident, 381-84; Matthias B. Lehmann, Emissaries from the Holy Land: The Sephardic Diaspora and the Practice of Pan-Judaism in the Eighteenth Century (Stanford: Stanford University Press, 2014), 73-76. 
The community of Bordeaux acted not only against the transgressions of the commandments but also against intellectual endeavors it considered to be in contradiction with Jewish dogma, learning, and tradition. Such was the punishment of Moize de Paz Dias in 1735, for "being stubborn and obstinate against the law of the Torah."14

The Bordeaux community, as a community of ex-Marranos, characteristically included a substantial number of free thinkers and skeptics. ${ }^{15}$ Unfortunately, our sources do not supply us with sufficient evidence to reconstruct the intellectual reasoning or the critical arguments of these early dissidents. Nevertheless, it is reasonable to assume that the general atmosphere among the elite circles of French society provided them with a rich treasure of critical thought. ${ }^{16}$

As part of the philosophers' attempts to study the various forms of government, social structures, and different social groups composing society and to explore ideas toward social reforms, they discussed the Jewish question. They delved into the stature and morality of the Jewish religion, the characteristics of the Jews, their social status, civil rights, importance in the economy, and the possibility of educating and integrating them as equal citizens in the state. ${ }^{17}$

In Isaac de Pinto's debate with Voltaire regarding the Jews, he argued that the Sephardic Jews were different from the other Jews and did not share their failings (although he defended them all the same). ${ }^{18}$ There was some truth to his allegation, since the characteristics of the Sephardic communities in the eighteenth century were quite different from those of the Ashkenazic communities in this period. Therefore, the new philosophical ideas and the development of the Jewish Enlightenment, the Haskala, influenced them differently. While the Jewish Enlightenment in the Ashkenazic communities of the Habsburg Empire and Prussia manifested itself mainly in a thirst for nonrabbinical knowledge and a demand for reform in the traditional Jewish education and communal hierarchy, ${ }^{19}$ the Sephardic educational tradition did not

\footnotetext{
14 Schwarzfuchs, Registre, 137.

15 On the characteristics of the Sephardi diaspora communities and the challenges they faced, see Yosef Kaplan, From New Christians to New Jews (Jerusalem: The Zalman Shazar Center, 2003).

16 Hertzberg, The French Enlightenment and the Jews, 29-48.

17 Ibid., 268-313.

18 Ibid., 181.

19 Shmuel Feiner, The Jewish Enlightenment (Philadelphia: University of Pennsylvania Press, 2004); David Sorkin, The Transformation of German Jewry, 1780-1840 (New York: Oxford University Press, 1987); Jay R. Berkovitz, Rites and Passages: The Beginnings of Modern
} 
view the pursuit of "external sciences" as being in opposition to the study of the Torah, since the Jewish tradition encompassed all knowledge. ${ }^{20}$ This attitude is exemplified in the person of Jacob Rodrigues Pereire, the representative of the Bordeaux community in Paris who was a practicing Jew and, at the same time, a scientist who initiated the education of deaf-mute children. ${ }^{21}$ Nevertheless, the Enlightenment had its influence on the Sephardic communities, and we shall explore here its manifestation and impact on the Bordeaux community in particular.

As the eighteenth century progressed, the winds of enlightenment and secularization that were blowing in Western Europe manifested themselves ever more clearly in the communities of southwestern France. In the course of Hida's visit in 1755 to the Sephardic community of Bayonne, the leaders showed him a fossil that had been sent from Spain to the Academy in Paris and was later exhibited in different cities. They explained to him that it was a tree that became a stone. In response, he remonstrated them for believing in the wisdom of the Gentiles and not in the Jewish wisdom, pointing out to them that the Talmud knew already of such transformations. ${ }^{22}$ The account of his 1777 visit in Bayonne mentions a señor Julian, one of the leaders of the community, who insinuated that all the Scriptures were a lie. He also mentioned some dignitaries who asked philosophical questions on souls and reward and punishment. ${ }^{23}$

In the account of his visit to Bordeaux, Hida criticized some of its dignitaries such as Shlomo López, the gabbay, and Avraham Gradis for not believing in the Sages, probably influenced by Spinoza's writings. He accused them of further transgressions of the rules of ritual purification and of eating forbidden foods in public, together with Yaakov Isidro, the evildoer, and his heretic sons who used to overtly break the Sabbath. He also mentioned other Sephardic

Jewish Culture in France, 1650-186o (Philadelphia: University of Pennsylvania Press, 2004), $35^{-} 5^{8}$.

20 Francesca Bregoli, Mediterranean Enlightenment: Livornese Jews, Tuscan Culture and Eighteenth-Century Reform (Stanford: Stanford University Press, 2014), 7.

21 On Jacob Rodrigues Pereire, see Renée Neher-Bernheim, "Jacob Rodrigue Pereire," Proceedings of the Seventh World Congress of Jewish Studies, History of the Jews in Europe (Jerusalem: World Union of Jewish Studies, 1977), 57-66; Neher-Bernheim, "Un savant juif engagé: Jacob Rodrigue Pereire (c. 1715-1780)," REJ 142 (1983): 313-451; Evelyne OlielGrausz, "Droit et espace Séfarade: Jacob Rodrigues Pereire et l'extension des privilèges. Du royaume à la Nation," Archives Juives 37, no. 1 (2004): 28-46.

22 Azulai, Ma'agal Tov ha-Shalem, 37.

23 Ibid., 110-13. 
dignitaries who debated with him on philosophy and expressed opinions bordering on heretical thought. ${ }^{24}$

Hida was also deeply disapproving of the Talmud Torah's curriculum for including only the Hebrew Scripture without any rabbinical exegesis, not even Rashi, leading him to claim that they didn't even teach Maimonides. Although in the same account Hida reported seeing the reading of the Bible and a chapter of Maimonides on the Sabbath in the Talmud Torah, his allegations were not altogether unfounded. ${ }^{25}$ As evident from the 1761 statutes of the Talmud Torah, the main subjects were learning to read Hebrew, translating the weekly Torah reading, Prophets, and Psalms from Hebrew to Spanish, as well as studying all the prayers of the year. ${ }^{26}$

The 1774 supplement to the statutes of the Talmud Torah states the curriculum for a future third class would be to comprehend the Hebrew grammar, and "the knowledge of our best commentaries, meaning of those who are the best grammarians, and are the most attached to the literal meaning of the text, which is the only way to understand the real duties that God prescribed us." ${ }^{27}$

These statutes and their supplements reflect the influence of the philosophical ideas of the Enlightenment, for instance the importance attached to understanding the literal meaning of the biblical text. In this context, it is relevant to mention the emphasis given to the cleanliness of the classrooms and the health of the students. But all this remains inside the sphere of traditional Sephardic spiritual culture. The statutes do not represent a radically new approach to Jewish education and to biblical studies, as opposed to the treatise on Jewish education by Hartwig Wessely published in Berlin in $1782 .{ }^{28}$

By the seventies, it appears that the concepts of reason and scientific logic expanded from the domain of a few free thinkers to the conventional way of thinking in the community of Bordeaux. The declaration of Isaac Rodriguez fils upon his appointment in $177^{2}$ as the new syndic of the Nation illustrates this influence. He reprehended the moral corruption due to the ignorance of their duties to the Creator prevalent mainly among the lower strata of the Jews, but was rapidly progressing. In order to repress this tendency, he advocated "a consistent education that will instill in our youth religious sentiments and morals appropriate to attract one day the good will of the nations or at least

\footnotetext{
24 Ibid., 114-15.

25 Ibid., 114.

26 Schwarzfuchs, Registre, 297-302.

27 Ibid., 443-51.

28 Feiner, The Jewish Enlightenment, 97-104.
} 
spare us their mockery. That will make them acknowledge their duties to God and to themselves." 29

However, the ideas of enlightenment did not obliterate the Jewish customs and way of life of the community of Bordeaux. Its leaders tried, out of sympathy toward the new ideas, to reconcile them with Jewish precepts and thought. As we shall see, in case of conflict, they preferred reason to tradition. This can be seen in a decision of the council of Elders to refer a divorce case to the consideration of the beit din, while declaring that "they will receive the opinion of the rabbinical court, and then the Nation will decide [on the matter] according to reason."30

This is even clearer in the council's decision in a case of bigamy presented to them. Because of the urgency of the case, they did not even refer it to the rabbinical court as ordinary, but decided on their own to annul the wedding. They justified their decision in these terms: "If it seems that the Torah does not forbid polygamy, the Nation could flatter itself, there has never been in its midst an example so destructive. And if the Easterners sometimes do it, the Nation still sees it as contrary to morality, public order, and the conjugal trust."31

The enlightenment influence can be found even in the words of Rabbi David Athias, Hakham Yaakov Athias's son, when he tried in 1768 to persuade a reluctant brother-in-law (a yavam $^{32}$ ) to release his widowed sister-in-law of her "aginut": 33 he "did his best with the voice of reason and the power of the Torah."34

At the close of the century David Gradis, one of the most influential leaders of the community, published a philosophical treatise in which he opposed the

\footnotetext{
29 Schwarzfuchs, Registre, 411-15.

$30 \quad$ Ibid., 549 .

31 Ibid., 508.

32 The Torah stipulates that in the case of a woman becoming a widow where she and her late husband have no offspring, one of her brothers-in-law must marry her to provide an offspring to his deceased brother. A brother-in-law in such circumstances is called a "yavam." He may fulfill his obligation, or perform the ceremony of "halitsa," in which the widow unties his sandal and spits in front of him (as described in the Torah as expressing her contempt for his refusal to provide her late husband with an offspring), and she is then free to marry someone else. Until then, the "yevama" is forbidden to remarry.

33 According to Jewish law, an "aguna" is a separated woman who is not permitted to remarry, because her husband is not proven dead, or because her husband refuses to deliver her a "get" (a divorce act and document) or has disappeared, putting her in a situation (aginut) where she is still bound by her married status and is unable to legally end her marriage. This situation being tragic, many ways are being explored by rabbinical judges in each case to end this status and allowing the woman to remarry.

Ibid., $382-83$.
} 
Sages' interpretations of the Bible and proposed to rescue the Scriptures from the Talmudists. ${ }^{35}$

During the first phases of this cultural evolution and these religiously challenging times, the community of Bordeaux was led by Hakham Yaakov Athias who had been appointed as the community's rabbi at the death of his predecessor, Hakham Yosef Falcon, in 1738. He served the Bordeaux community until his death in 1760 . The nomination of the son and heir of a Portuguese family of rabbis established at Bidache to officiate as the rabbi of Bordeaux was a significant milestone in the process of building the Bordeaux community. It marked its transition from a group of New Christians who were clandestinely performing Jewish ceremonies to an established Jewish community recognized by the Jewish world. The nomination of a local rabbi proved its ability to lead its own religious life, no longer obliged to import a rabbi from outside, as was Hakham Falcon, who came from Jerusalem.

Hakham Yaakov Athias devoted considerable efforts during his tenure to fighting the transgressions of religious commandments by some members of the community and their contempt for the Torah. His term of office is replete with conflicts between himself and the leadership of the community, as we can see from various resolutions recorded in the register, conflicts which reached their peak with his suspension from office.

According to Nahon, Yaakov Athias originated from the Athias family of Bidache, a little town near Bayonne, which provided circumcisers, cantors, and rabbis to surrounding communities. ${ }^{36} \mathrm{He}$ arrived in Bordeaux in 1725 when he was about forty-five years old. He began his public service as a cantor and in 1732, he was appointed as the teacher of the community school. ${ }^{37} \mathrm{His}$ public role must have been important since already in the 1733 report of Monsieur Pudeffer, he is mentioned along with Hakham Falcon as one of the rabbis of the community. ${ }^{38}$ His signature appears with that of Hakham Falcon on several decisions of the council of Elders as well as on the regulation of the Nation in 1736.39

35 Hertzberg, The French Enlightenment and the Jews, 157-160.

36 Gérard Nahon, "Le registre espagnol des circoncisions de Samuel Gomes Atias (Bidache, 1725-1773)," Bulletin Hispanique 76 (1974): 150.

37 Schwarzfuchs, Registre, 128.

38 Archives Départementales de la Gironde, C 1089, n. 43; Schwarzfuchs, Registre, 6oo-1.

39 Schwarzfuchs, Registre, 126, 137, 138-42. 
Upon the death of Hakham Falcon in 1738, Hakham Athias was appointed as hakham of the community. However, his appointment specified certain conditions that defined and limited his authority, such as a prohibition to impose any sort of punishment or to publish anything against any member of the Nation without the approval of the secular leadership. ${ }^{40}$

Hakham Yaakov Athias assumed the responsibility of supervising the manufacturing of the kosher wine and the baking of the matsot for Passover. He decided on the halakhic aspect of the cases of clandestine weddings in order to annul them, and tested and appointed ritual slaughterers. In most of these functions, he clashed with the council of elders in what seems to have been a struggle about his position in the community's hierarchy. Nevertheless, the epitaph on the stately gravestone of Hakham Yaakov Haim Athias in the cemetery of Bordeaux acknowledges his contribution, praising him for teaching the hakhamim, deepening the knowledge of the commandments of God in the people and lighting the fire of the Torah in their hearts. ${ }^{41}$

\section{5}

\section{Correspondence}

As part of Hakham Athias's tactics or even his strategy to ameliorate his position in the community's leadership and to influence his parishioners in the face of religious challenges, he turned for help to external factors. In a letter to the Intendant of Bordeaux, head of the local royal administration that can convincingly be attributed to Hakham Athias, the Hakham asks the Intendant to "rebuke the head of the Portuguese Nation, on the scarcity of honor and importance in which they hold their rabbi."42 Hakham Athias also corresponded with the hakhamim and the Mahamad of the community of Amsterdam. He begged for their support and wished them to back his efforts in preserving the adherence of his flock to a normative Jewish life on the one hand, and in fighting the dissenters on the other, asking them to admonish his parishioners on the gravity of their actions. Of this correspondence, only the letters of reply from Amsterdam, copied in the "copiador de cartas" of the Talmud Torah Congregation in Amsterdam reached us. These responses testify to the painful and passionate appeals of Hakham Athias for their help.

As expected from the very nature of reply letters, it is often difficult to clearly understand the issue the original letter dealt with. A reply letter signed by the

40 Ibid., 149-50.

41 Cirot, Recherches sur les Juifs espagnols et portugais à Bordeaux, 133.

42 Archives départementales de la Gironde, C 1090, n. 123. 
hakhamim and parnassim of the community of Amsterdam to Hakham Athias from December 1746, reflects the emotional and painful character of Hakham Athias's letter and the problems he was facing: "The contents of the letter your honor wrote us moved us so much that we didn't know what to think. The subject on which his honor with such sad reasons wrote us, excited our souls with the proper tenderness in order to act with his honor to our best ability, to help him in his worthy objective to face effectively the despicable abuses of the observance of the Divine commandments practiced in this community, which he describes so painfully and for which he implores our help."43

They suggest to write to the parnassim and leaders of the community of Bordeaux to induce them to support the Hakham in his goal to find a suitable means to remove the evil, and encourage him that "Since your honor, as an experienced shepherd, knows the individual characters of the transgressors, he will be able to find, with the concurrence of the gentlemen of the Mahamad, the right approach to convince each of them to leave his evil and erroneous way, and wish to return to the Divine grace." ${ }^{44}$

Indeed, on the same day, the hakhamim and parnassim of Amsterdam wrote a more elaborate letter to the parnassim and gabbay of the community of Bordeaux, declaring "the transgressions of our religion, the Divine precepts and their fences instituted by our sages committed by their flock, are famous and notorious." 45

They admonish them about the fact that under their leadership, very serious offenses were committed, including the marriage of a mamzer, ${ }^{46}$ against the ruling of Hakham Athias. They warn them that members of the community, from material reasons, will try to harm the observance of the major religious commandments: observance of the Sabbath, the purity of women, and kosher foods, whose objective is to separate the exiled Jewish people from the surrounding nations. They recommend to appeal to sinners with love and care and to try to persuade them to leave their evil way, while those who refuse should be alienated from the community, "because he who is a Jew only in name, is no Jew." The parnassim should avoid "dealing patiently with such severe and sinful issues." They stress the mutual responsibility of the Jewish

\footnotetext{
43 SAA 334/ 5.1.1.92, Copiador de cartas 1744-1750, pp. 148-49.

44 Ibid.

45 SAA 334/ 5.1.1.92, Copiador de cartas 1744-1750, 29 Kislev 5507, pp. 149-50, and in OlielGrausz, "Relations et réseaux," 504-5.

46 According to Jewish law, mamzer is a Jewish person who was born from a union severely prohibited, such as adultery (a married woman with another man), or incest. Although translated as "bastard," mamzer differs in its legal definition and does not cover the same cases.
} 
people, since the sinners affect the whole people by bringing the wrath of God upon it, while keeping the Torah will ensure God's blessing and his goodness.

The parnassim and gabbay of Bordeaux replied to this letter by rejecting the claims of the hakhamim and the Mahamad of Amsterdam, and indirectly Hakham Athias's claims, and describing the good order prevailing in the community and their observance of the commandments. Nevertheless, the Mahamad of Amsterdam recommended that they heed their reproaches, admonitions that were based on Hakham Athias's depiction of the situation. ${ }^{47}$

The appeal of Hakham Athias to the hakhamim of Amsterdam and their response apparently affected the leadership of the community of Bordeaux. Two years later, in September 1748, we find in the community register the record of a deliberation regarding a certain "Joseph Rodrigues Pereira, advocate, and his son, and Raphael Dacosta, who speak incessantly with intolerable indiscretion against the most sacred dogmas of the religion, and consequently act in a scandalous manner and transgress the Sabbath and our holy days." ${ }^{38}$ The council of elders decided to warn them but since they refused to attend the meeting and continued with their bad behavior in public, they were summoned again to a meeting. They were fined and ordered to come on the Eve of Kippur to a certain place in order to ask for forgiveness from God, and to promise to renounce their sins. As again they didn't comply, the council banned them from the community and forbade the members to have any communication with them. Three days later, the dissenters renounced their opinions, asked for forgiveness from God and the people, and paid the fines to charity, upon which, Hakham Athias, with two other persons, removed the ban. ${ }^{49}$ In $175^{1}$ the council also punished Monsieur Pesoua for transgressing Passover. ${ }^{50}$ Nevertheless, in 1754 Hakham Athias wrote again to Amsterdam and presented "the sad situation of some members of the community who compromise on such essential points of our sacred law [...] especially since they don't adhere to his warnings." ${ }^{51}$

In July 1755 after receiving another letter from Hakham Athias, the parnassim of Amsterdam wrote to their counterparts in Bordeaux and implored them to listen to the good doctrine of Hakham Athias and support his actions, and to punish the transgressors of the sacred law. ${ }^{52}$

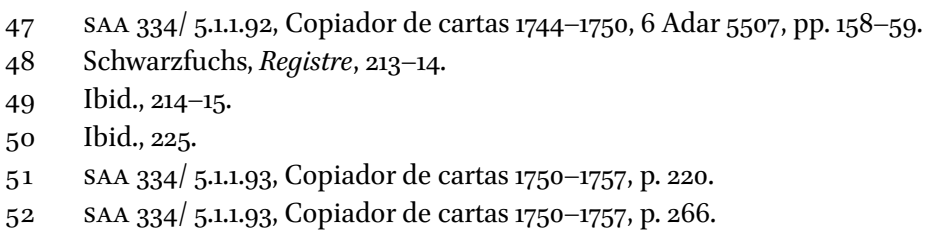


Eventually, the struggle of Hakham Athias against religious laxity and attacks on traditional Jewish thought and dogmas could not stop the advancement and propagation of the ideas of the Enlightenment among the community of Bordeaux. But perhaps, his efforts to maintain the fidelity of his flock to the Torah and to the observance of its precepts did help to consolidate in Bordeaux a certain kind of Judaism. A communal Jewish way of life was preserved: prayers in the synagogues, Sabbaths and holidays with their specific customs, the life-cycle ceremonies, studying Hebrew and the Torah at the communal school, along with a rich social life that was conducted in the various mutual aid religious societies. This commitment, both ritual and social, even without a halakhic observance of Judaism from a growing part of its members, and in spite of the acceptance of the concepts of Enlightenment and the later integration into the French intellectual sphere, enabled the continuing existence of this community.

\section{Bibliography}

Azulai, Haim Yosef David. Ma'agal Tov ha-Shalem. Edited by Aharon Freiman. Jerusalem: Merkaz Hasefer, 1983.

Beaufleury, Louis Francia. Histoire de l'établissement des Juifs à Bordeaux et à Bayonne depuis 1550. Paris, an 8 [1800].

Beinart, Haim, ed. Moreshet Sepharad: The Sephardi Legacy. 2 vols. Jerusalem: Magnes Press, 1992.

Berkovitz, Jay R. Rites and Passages: The Beginnings of Modern Jewish Culture in France, 1650-186o. Philadelphia: University of Pennsylvania Press, 2004.

Bregoli, Francesca. Mediterranean Enlightenment: Livornese Jews, Tuscan Culture and Eighteenth-Century Reform. Stanford: Stanford University Press, 2014.

Cirot, Georges. Les Juifs de Bordeaux. Leur situation morale et sociale de 1550 à la Révolution. Bordeaux: Feret, 1920.

Cirot, Georges. Recherches sur les Juifs espagnols et portugais à Bordeaux. Bordeaux: Feret \& Fils, Éditeurs, 1908.

Detcheverry, Arnaud. Histoire des israélites de Bordeaux. Bordeaux: Balarac jeune, $185^{\circ}$.

Feiner, Shmuel. The Jewish Enlightenment. Philadelphia: University of Pennsylvania Press, 2004.

Graizbord, David L. Souls in Dispute: Converso Identities in Iberia and the Jewish Diaspora, 1580-1700. Philadelphia: University of Pennsylvania Press, 2004. 
Hertzberg, Arthur. The French Enlightenment and the Jews: The Origins of Modern AntiSemitism. New York: Schocken Books, 1968.

Kaplan, Yosef. From New Christians to New Jews. Jerusalem: The Zalman Shazar Center, 2003. [Hebrew]

Lehmann, Matthias B. Emissaries From the Holy Land: The Sephardic Diaspora and the Practice of Pan-Judaism in the Eighteenth Century. Stanford: Stanford University Press, 2014.

Malino, Frances. The Sephardic Jews of Bordeaux. Alabama: University of Alabama Press, 1978.

Malvezin, Thzéophile. Histoire des juifs a Bordeaux. Bordeaux: Charles Lefebvre, Libraire, 1875 .

Nahon, Gérard. "From New Christians to the Portuguese Jewish Nation in France." In Moreshet Sepharad, Edited by Haim Beinart, 2: 336-364. Jerusalem: Magnes Press, 1992.

Nahon, Gérard. Juifs et judaïsme à Bordeaux. Bordeaux: Mollat, 2003.

Nahon, Gérard. "Le registre espagnol des circoncisions de Samuel Gomes Atias (Bidache, 1725-1773)." Bulletin Hispanique 76 (1974): 142-182.

Nahon, Gérard. Les "Nations” juives portugaises du sud-ouest de la France (1684-1791): Documents. Paris: Fundação Calouste Gulbenkian, Centro Cultural Português, 1981.

Nahon, Gérard. Métropoles et périphéries Séfarades d'occident. Paris: Cerf, 1993.

Neher-Bernheim, Renée. "Jacob Rodrigue Pereire." Proceedings of the Seventh World Congress of Jewish Studies, History of the Jews in Europe. Pp. 57-66. Jerusalem: World Union of Jewish Studies, 1977.

Neher-Bernheim, Renée. “Un savant juif engagé: Jacob Rodrigue Pereire (c. 1715-1780).” Revue des Études Juives 142 (1983): 313-451.

Oliel-Grausz, Evelyne. “Droit et espace Séfarade:Jacob Rodrigues Pereire et l'extension des privilèges. Du royaume à la Nation." Archives Juives 37 no. 1 (2004):28-46.

Oliel-Grausz, Evelyne. "La diaspora séfarade au XVIII e siècle: communication, espaces, réseaux." Arquivos do Centro Cultural Calouste Gulbenkian 48 (2004): 55-71.

Oliel-Grausz, Evelyne. "Relations et réseaux intercommunautaires dans la diaspora séfarade d'occident au XVIII' siècle." PhD diss.: University of Paris, 1999.

Sahlins, Peter. Unnaturally French: Foreign Citizens in the Old Regime and After. Cornell University Press, 2004.

Schwarzfuchs, Simon. Registre des deliberations de la Nationjuive Portugaise de Bordeaux 1710-1787. Paris: Fundação Calouste Gulbenkian, Centro Cultural Português, 1981.

Sorkin, David. The Transformation of German Jewry, 1780-1840. New York: Oxford University Press, 1987. 